\title{
Maturational differences in lung NF-אB activation and their role in tolerance to hyperoxia
}

\author{
Guang Yang, ${ }^{1}$ Aida Abate, ${ }^{2}$ Adia G. George, ${ }^{2}$ Yi-Hao Weng, ${ }^{2}$ and Phyllis A. Dennery 1,3 \\ 1Division of Neonatology, Children's Hospital of Philadelphia, Philadelphia, Pennsylvania, USA. \\ 2Stanford University School of Medicine, Stanford, California, USA. ${ }^{3}$ Department of Pediatrics, University of Pennsylvania School of Medicine, \\ Philadelphia, Pennsylvania, USA.
}

\begin{abstract}
Neonatal rodents are more tolerant to hyperoxia than adults. We determined whether maturational differences in lung NF- $\kappa B$ activation could account for the differences. After hyperoxic exposure $\left(\mathrm{O}_{2}>95 \%\right)$, neonatal ( $<12$ hours old) lung NF- $\kappa B$ binding was increased and reached a maximum between 8 and 16 hours, whereas in adults no changes were observed. Additionally, neonatal NF- $\kappa \mathrm{B} /$ luciferase transgenic mice (incorporating 2 $N F-\kappa B$ consensus sequences driving luciferase gene expression) demonstrated enhanced in vivo NF- $\kappa B$ activation after hyperoxia in real time. In the lungs of neonates, there was a propensity toward NF- $\kappa \mathrm{B}$ activation as evidenced by increased lung I- $\kappa B$ kinase protein levels, I- $\kappa B \alpha$ phosphorylation, $\beta$-transducin repeat-containing protein levels, and total I- $\kappa B \alpha$ degradation. Increased lung $\mathrm{p}-\mathrm{JNK}$ immunoreactive protein was observed only in the adult lung. Inhibition of $\mathrm{pI}-\kappa \mathrm{B} \alpha$ by BAY 11-7085 resulted in decreased Bcl-2 protein levels in neonatal lung homogenates and decreased cell viability in lung primary cultures after hyperoxic exposure. Furthermore, neonatal $\mathrm{p} 50$-null mutant $\left(\mathrm{p50}^{-/-}\right)$mice showed increased lung DNA degradation and decreased survival in hyperoxia compared with WT mice. These data demonstrate that there are maturational differences in lung NF- $\kappa B$ activation and that enhanced NF- $\kappa B$ may serve to protect the neonatal lung from acute hyperoxic injury via inhibition of apoptosis.
\end{abstract}

\section{Introduction}

Prolonged hyperoxic exposure $\left(\mathrm{O}_{2}>95 \%\right)$ causes severe lung injury and mortality in adult rodents. However similarly exposed neonatal rodents are more tolerant of hyperoxia (1). Some studies have demonstrated that increased antioxidant enzyme (AOE) activities and a reduced superoxide-generating capacity contribute to tolerance of hyperoxia in the neonatal lung (2-4). In adults, pre-exposure to hyperoxia or pretreatment with endotoxin (LPS) or inflammatory cytokines can prevent further lung damage and increase survival under hyperoxia (5-10). In these situations, induction of cytokines and increased AOEs were the major factors accounting for this "acquired" tolerance to hyperoxia. Nonetheless, differences in transcription factor activation may also contribute (11-13), since transcription factors regulate cytokine, apoptosis, and antioxidant (AOE) gene expression. We have previously observed that, unlike adult lungs, neonatal lungs did not activate AP-1 in hyperoxia (14). In the present report, we demonstrate that neonatal lungs preferentially activate NF- $\kappa \mathrm{B}$, a transcription factor that governs inflammatory processes and apoptosis.

The consensus sequence for NF- $\mathrm{KB}$ is found in genes that respond to oxidative stress, inflammation, and apoptosis. Five members of

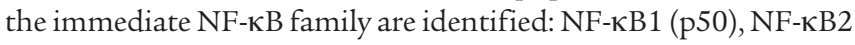
(p52), p65/RelA, RelB, and cRel. The most abundant subunits of NF-кB are p65/RelA and p50. In most cases the hypophosphorylat-

Nonstandard abbreviations used: AOE, antioxidant enzyme; IKK, I-кB kinase; luc, luciferase; MeKK-1, MAPK/extracellular signal-regulated kinase kinase kinase-1; MnSOD, manganese superoxide dismutase; $\mathrm{Tg}$, transgenic; $\beta$-TrCP, $\beta$-transducin repeat-containing protein.

Conflict of interest: The authors have declared that no conflict of interest exists.

Citation for this article: J. Clin. Invest. 114:669-678 (2004)

doi:10.1172/JCI200419300. ed form of the inhibitor protein I- $\kappa \mathrm{B}$ binds to NF- $\kappa \mathrm{B}$ and maintains an inactive state in the cytoplasm. Many I- $\kappa \mathrm{B}$ family proteins have been identified, including I- $\kappa \mathrm{B} \alpha$, I- $\kappa \mathrm{B} \beta$, I- $\kappa \mathrm{B} \varepsilon, \mathrm{Bcl}-3, \mathrm{p} 100 / \mathrm{I}-\kappa \mathrm{B} \delta$,

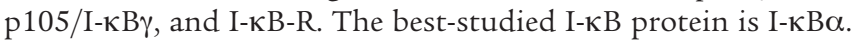

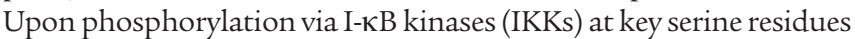
(ser32 and ser36), I-кB $\alpha$ is ubiquitinated and degraded to allow for translocation of NF- $\kappa \mathrm{B}$ into the nucleus. This process requires the recognition of phosphorylated $\mathrm{I}-\kappa \mathrm{B}$ by $\beta$-transducin repeat-containing protein $(\beta-\operatorname{TrCP})$. Thereafter, NF- $\kappa \mathrm{B}$ binds to target DNA sequences and initiates gene transcription. An alternative NF-кB activation pathway was also described involving PI3K-mediated

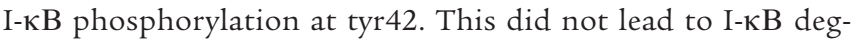
radation (15). This IKK-independent pathway is important for $\mathrm{NF}-\kappa \mathrm{B}$ activation by oxidants and is controlled by upstream phosphorylation events involving MAPK/extracellular signal-regulated kinase kinase kinase-1 (MeKK-1) $(16,17)$.

Many studies have documented detrimental effects of NF- $\mathrm{B}$ activation when it is dysregulated. However, NF- $\kappa \mathrm{B}$ activation also protects cells from apoptosis induced by TNF- $\alpha$, $x$-ray irradiation, and chemotherapeutic agents (18-21). Whether NF- $\mathrm{KB}$ acts as an anti- or a proapoptotic mediator is determined by the nature of the stimulus and the cell type (22). Hyperoxic exposure of lung alveolar epithelial cells results in both apoptosis and necrosis. In one model, hyperoxia-induced NF-кB activation did not protect the cells from necrosis (23), but in another, it inhibited further oxidant-induced apoptosis (24). Interestingly, hyperoxia alone did not activate NF- $\kappa \mathrm{B}$ in adult lung alveolar macrophages, whereas changes in $\mathrm{O}_{2}$ tension significantly altered NF- $\mathrm{\kappa B}$ activation in perinatal lung cells (25), suggesting maturational differences in $\mathrm{NF}-\kappa \mathrm{B}$ activation. We hypothesized that maturational differences in hyperoxic activation of NF- $\mathrm{KB}$ are important determinants of 

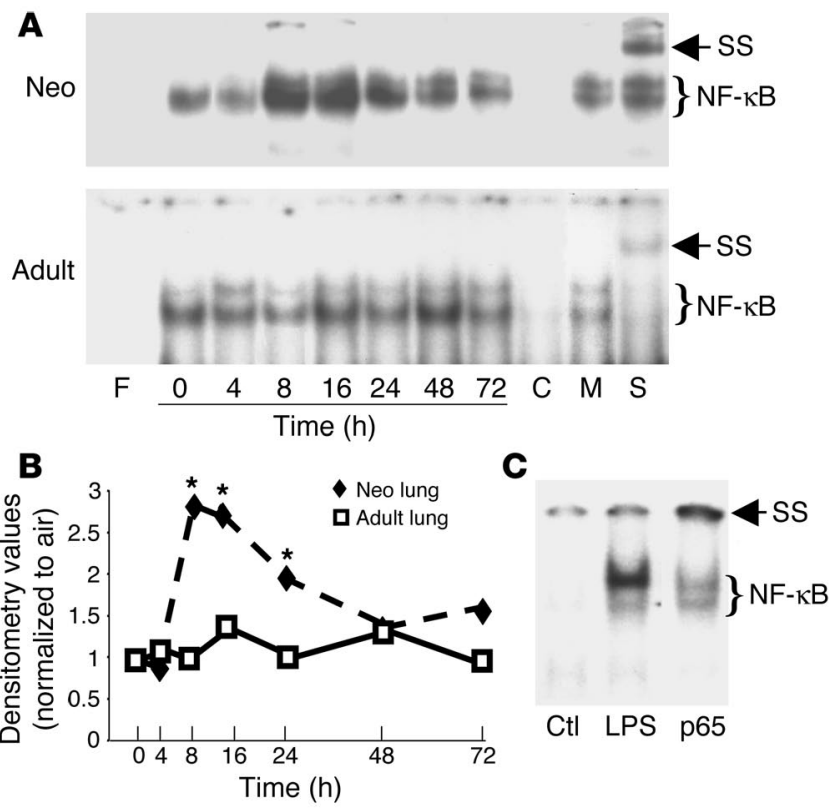

hyperoxic tolerance. We also evaluated whether these differences could be explained by upstream events involving IKK. We also examined whether downstream events of NF-кB involving inflammation and apoptosis can explain neonatal hyperoxic tolerance.

\section{Results}

\section{Maturational differences in lung NF- $\kappa B$ activation}

Lung NF-KB binding increases in the neonatal lung but not in the adult after hyperoxia. After 8 hours of hyperoxic exposure, NF-кB binding in neonatal lungs increased 2.7 -fold and remained elevated for 72 hours compared with that in air-exposed controls (Figure 1). In contrast, hyperoxia-exposed adult lungs did not show increased

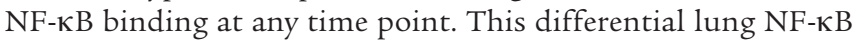
activation between the neonates and the adults was documented in

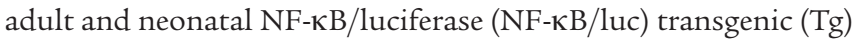
mice in vivo in real time (Figure 2). After 20 hours of hyperoxia, neonatal NF-KB/luc Tg mice demonstrated a significant, threefold increase in lung NF- $\mathrm{\kappa B}$ activation as indexed by photon emission (relative intensity units per lung area; $P<0.05, n=3$ in each group). Additionally, immunoreactive luciferase protein was detected in bronchiolar and alveolar epithelium as well as endothelial cells, which indicated NF- $\kappa \mathrm{B}$ activation in these cells after hyperoxic exposure (Figure 2B, left and middle panels). Furthermore, coim-

\section{Figure 2}

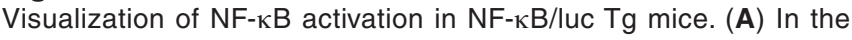
pseudoimages, the blue to red coloring represents the lowest to the highest light intensity. 0-72 hours, duration of hyperoxia. (B) Immunohistochemical staining of luciferase protein in the neonatal lung after 24 hours of hyperoxia. Luciferase protein was localized to bronchiolar and alveolar epithelial cells (lower left and middle panels, white arrows) as well as endothelial cells (lower left panel, arrowhead). Colocalization of the luciferase (red) and alveolar macrophage CD68 (green) is demonstrated by yellow-colored cells (lower right panel, yellow arrow). Note that the luciferase protein is not exclusively localized to the macrophages.

\section{Figure 1}

Demonstration of hyperoxia-mediated neonatal (Neo) lung NF-кB activation in C57BL/6 mice. (A) Representative of 3 EMSA blots. $\mathrm{F}$, free probe; $0-72 \mathrm{~h}$, duration of hyperoxia; $\mathrm{C}$, competition with 100 -fold excess of unlabeled oligonucleotide probe; $M$, competition with 100 -fold excess of unlabeled mutated oligonucleotide probe; S, supershift with p50 antibody in lung extract collected at 8 hours of hyperoxia; SS, supershift retardation band. (B) Densitometric evaluation of the EMSA blots. Densitometric units were expressed as a ratio of air-exposed values. The data are the mean \pm SE of 3 separate experiments. ${ }^{*} P<0.05$ vs. similarly exposed adults. (C) NF-kB activation in the neonatal LPS-injected lung. LPS $(20 \mathrm{mg} / \mathrm{kg})$ was injected intraperitoneally into 5-day-old C57BL/6 mice. Ctl, mice injected with PBS as vehicle control; LPS, 1 hour after injection with LPS; p65, sample as in LPS lane incubated with p65 antibody. Note: The decreased NF- $\mathrm{KB}$ complex and the supershift gel retardation band demonstrating the binding complex are specific to p65 in this model.

munostaining with an alveolar macrophage marker, CD68, demonstrated that NF- $\kappa \mathrm{B}$ activation also occurred in macrophages but not exclusively in these cells (Figure 2B, right panels).

Specificity of the $p 50$ subunit in the $N F-\kappa B$ complex after byperoxia. To

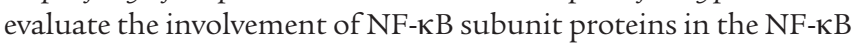
complex after hyperoxic exposure, antibodies against p50, p52, $\mathrm{p} 65$, RelB, and cRel were added to the nuclear proteins prior to the binding reaction. Only addition of p50 antibody resulted in a supershift retardation of the NF- $\kappa \mathrm{B}$ complex in both neonates and adults (Figure 1A). Lack of p65 specificity of the NF-кB complex could not be blamed on the $\mathrm{p} 65$ antibody used, because incubation of the same p65 antibody with LPS-injected neonatal lung nuclear extracts resulted in a lesser DNA binding and a supershiftretarded band (Figure 1C).

Hyperoxia-exposed neonates have increased lung $p I-\kappa B \alpha$ and $\beta-T r C P$ and decreased total $I-\kappa B \alpha$. To evaluate whether hyperoxia-mediated NF- $\kappa B$ activation resulted from increased degradation of the inhibitor pro-

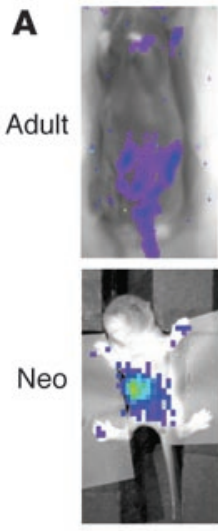

0

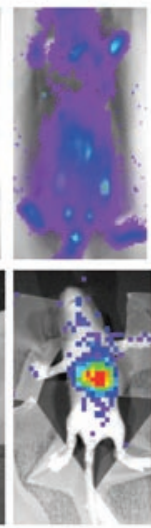

20

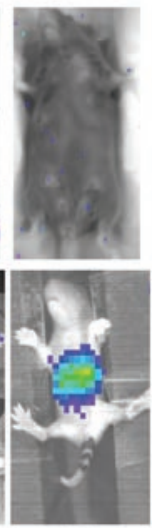

48

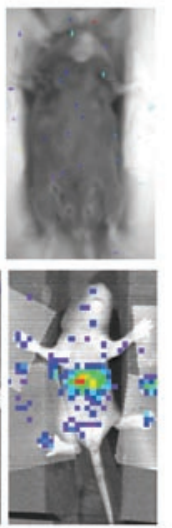

72

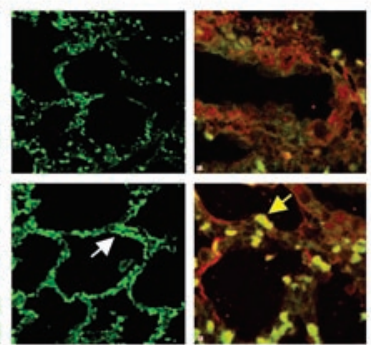

B

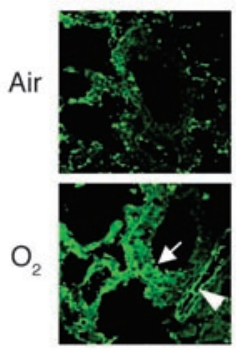

(h) 
A

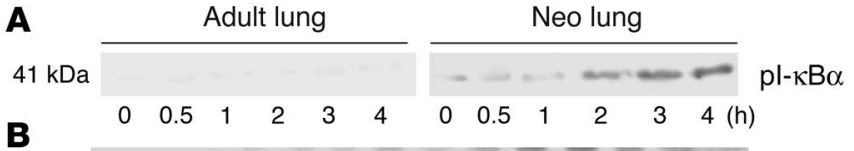

B
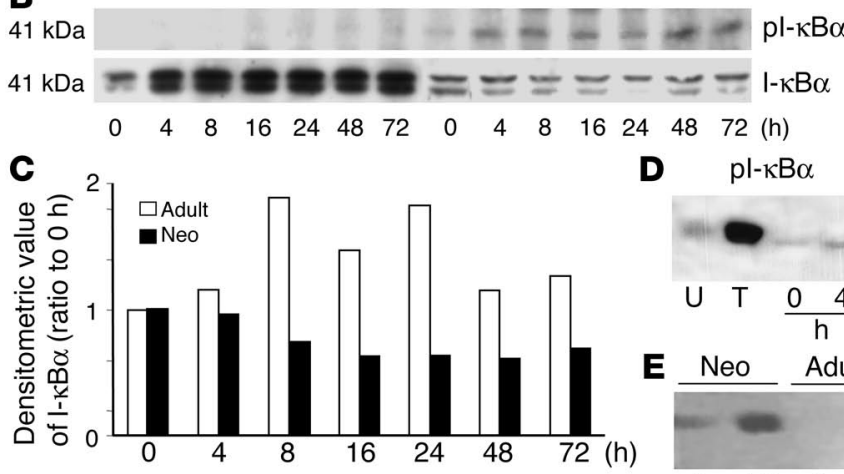

D $\mathrm{pl}-\mathrm{kB} \alpha$

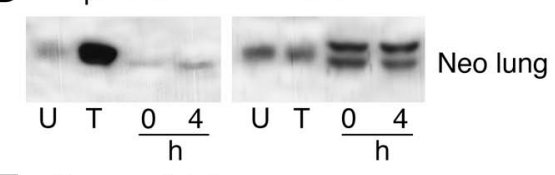

E $\mathrm{NeO}$

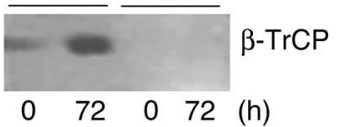

Figure 3

Maturational differences in $\mathrm{pl}-\kappa \mathrm{B} \alpha$, total $\mathrm{I}-\kappa \mathrm{B} \alpha$, and $\beta-\mathrm{TrCP}$ in hyperoxia. (A) Expression of $\mathrm{pl}-\kappa \mathrm{B} \alpha$ at early time points. $0-4$ hours, duration of hyperoxia. (B) Expression of $\mathrm{I}-\mathrm{kB} \alpha$ from 0 to 72 hours of hyperoxia. (C) Densitometric evaluation of $\mathrm{I}-\mathrm{\kappa B} \alpha$ protein levels from the blot shown in B. (D) Relative mobility of the $\mathrm{I}-\mathrm{\kappa B} \alpha$ bands after hyperoxia as compared with that in cell extracts with (T) or

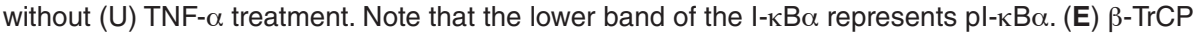
protein levels after hyperoxia in the nuclear fractions of the mouse lung.

tein I- $\mathrm{KB} \alpha$, neonatal and adult lung tissues were collected at early time points during hyperoxic exposure. Neonatal lung showed an increase in $\mathrm{pI}-\mathrm{\kappa B} \alpha$ protein levels after only 30 minutes of hyperoxia and a decrease in total I- $\mathrm{\kappa B} \alpha$ by 4 hours of hyperoxic exposure (Figure 3). In contrast, adults had barely detectable $\mathrm{pI}-\kappa \mathrm{B} \alpha$ and had increased total lung I- $\kappa \mathrm{B} \alpha$ protein levels at all time points after hyperoxic exposure (Figure 3). Additionally, after 72 hours of hyperoxia, neonates showed an increased level of $\beta-\operatorname{TrCP}$, a protein that targets $\mathrm{pI}-\mathrm{kB} \alpha$ for degradation, whereas adults showed no detectable levels of this protein (Figure 3E). This also suggested

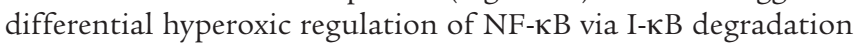
during maturation. When mice aged $0-60$ days were exposed to hyperoxia for 72 hours, the youngest animals had the lowest total lung cytosolic I- $\mathrm{kB} \alpha$, further suggesting a maturational difference in hyperoxic regulation of I-KB (Figure 4).

Maturational differences in lung IKK and p-JNK in hyperoxia. Oxidative activation of NF- $\mathrm{KB}$ can be regulated by I- $\mathrm{\kappa B}$ degradation via IKK and also by alternative pathways involving $\mathrm{p}-J \mathrm{NK}$. To understand what regulates hyperoxia-mediated lung I-кB expression, we assayed mice aged 0-60 days for subunits of IKK, total JNK, and p-JNK protein levels. Hyperoxia was associated with increased lung IKK- $\alpha$ and IKK- $\beta$ but not increased IKK- $\gamma$, whereas adults showed no increase in IKK- $\alpha$, loss of IKK- $\gamma$, and a modest increase in IKK- $\beta$ (Figure 4). This documents that neonates have relatively increased IKK protein levels. In contrast, adults had increased p-JNK, whereas neonates did not (Figure 4). However this increased p-JNK was not associated with increased NF-KB activation in adults.

\section{Downstream effects of $N F-\kappa B$ activation in hyperoxia}

Neonatal lungs have decreased proinflammatory cytokines after byperoxia. Because NF- $\mathrm{kB}$ activation regulates lung inflammatory cytokine levels, a panel of pro- and antiinflammatory cytokine mRNAs were evaluated in the adults and neonates exposed to hyperoxia. Lung TNF- $\alpha$ and IL- $1 \beta$ mRNAs were decreased in the neonates after 72 hours of hyperoxia; however, there were no changes in lung TGF- $\beta$ and GM-CSF mRNAs (Figure 5). In the adults, no changes were observed in any cytokine levels measured (Figure 5). Lung TNF- $\alpha$ protein levels showed a decreasing trend in the neonates after hyperoxia, but this did not reach statistical significance as demonstrated by densitometric evaluation of Western blots (hyperoxic exposure resulted in TNF- $\alpha$ levels that were $68 \% \pm 12 \%$ of air-exposed values; $P=0.09, n=3$ in each group).

Hyperoxia increases Bcl-2 levels in neonatal lung. Because NF- $\mathrm{\kappa B}$ activation inhibits apoptosis, we wanted to understand whether NF-кB activation regulated downstream anti- or proapoptotic genes in the neonatal lungs exposed to hyperoxia. Lung Bcl-2 mRNA and protein increased in the neonatal but not in the adult lungs (Figure 6, A and B). Immunohistochemical staining with $\mathrm{Bcl}-2$ antibody showed that increased $\mathrm{Bcl}-2$ protein in the neonatal lung was localized predominantly to the alveolar epithelial cells (Figure $6 \mathrm{C}$, arrowhead). In contrast, proapoptotic Bax protein levels did not change in either neonates or adults (Figure 6B). Overall, these experiments suggest that there is $\mathrm{Bcl}-2$ induction after hyperoxiamediated NF- $\mathrm{KB}$ activation in the neonates.

Hyperoxia for 72 hours does not increase apoptosis in neonatal lungs. In agreement with the increased lung Bcl-2 protein levels, there was no change in apoptosis in the neonatal lungs whereas adults showed a dramatic increase in TUNEL-positive staining after 72 hours of hyperoxia (Figure 6D).

\section{Effects of NF- $\mathrm{K} B$ inactivation in vitro and in vivo}

Inbibition of $\mathrm{I}-\mathrm{K} B$ phosphorylation decreases primary lung cell viability in byperoxia. As indexed by photon emission, neonatal NF- $\mathrm{\kappa B} / \mathrm{luc}$ primary lung cells showed increased NF-kB activation compared with

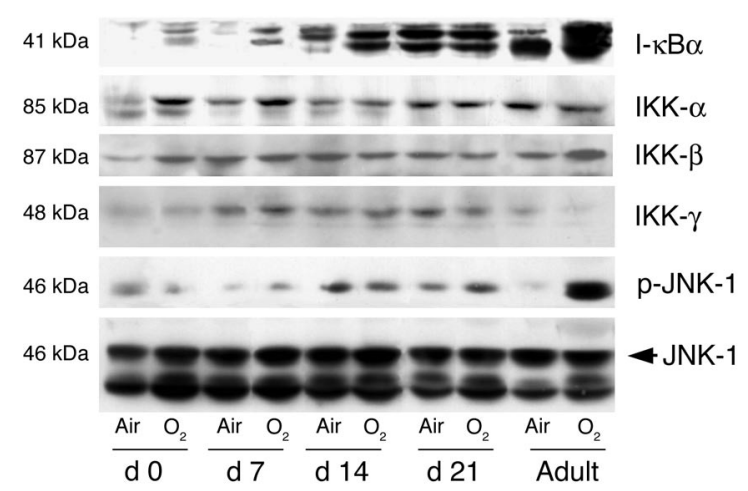

Figure 4

Maturational differences in total I-KB $\alpha$, IKK core subunit, p-JNK, and JNK protein levels in hyperoxia. Mice aged 0 days, 7 days, 14 days, 21 days, and 60 days (adult) were exposed to air or hyperoxia $\left(\mathrm{O}_{2}\right)$ for 72 hours. A representative of 3 Western analyses is shown. 


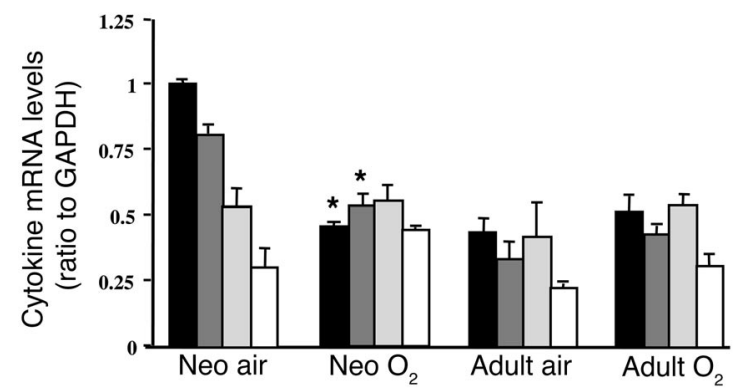

Figure 5

Levels of pro- and antiinflammatory cytokine mRNA in the lungs of mice exposed to air or 72 hours of hyperoxia. Densitometric values were expressed as a ratio to GAPDH. Values represent the mean \pm SE of 3 separate experiments. ${ }^{*} P<0.05$ vs. air-exposed mice. Black bars, TNF- $\alpha$; dark gray bars, IL- $1 \beta$; light gray bars, TGF- $\beta$; white bars, GM-CSF.

those of adults after 2 hours of hyperoxia (Figure 7A). Incubation with 1 mM BAY 11-7085 or BAY 11-7082 prior to exposure com-

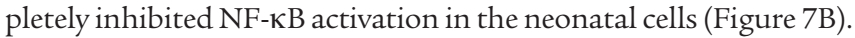
This was also associated with decreased cell viability (Figure 7C), suggesting a protective role of NF- $\mathrm{KB}$ activation in hyperoxia.

To verify the inhibitory effect of BAY on NF- $\kappa B$ activation in

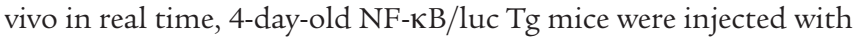
BAY 11-7085 and exposed to hyperoxia for 24 hours after luciferin injection. Photon emission decreased to $60 \%$ of pre-exposure levels, indicating inhibition of NF- $\mathrm{KB}$ by BAY 11-7085 in the lungs of the live animals as well (Figure $8, \mathrm{~A}$ and $\mathrm{B}$ ). This inhibition was also associated with decreased lung $\mathrm{pI}-\kappa \mathrm{B} \alpha$ and $\mathrm{Bcl}-2$ immunoreactive protein levels as shown in lung homogenates of C57BL/6 mice exposed to hyperoxia (Figure 8C).

p50-/- neonatal lungs are more susceptible to byperoxic injury than WT. Hyperoxic exposure was associated with increased inflammatory cells in the lungs of $\mathrm{p} 50^{-/-}$neonatal mice compared with similarly exposed WT mice (Figure 9A). Furthermore, lung TNF- $\alpha$ protein levels were increased in the p50-/- neonatal mice after 72 hours of hyperoxia ( $124 \% \pm 3 \%$ vs. $68 \% \pm 12 \%$ for $\mathrm{p} 50^{-/-}$vs. WT; values are the mean percentage \pm SE of air-exposed; $P=0.007, n=3$ in each group). These data suggest that absence of NF- $\kappa \mathrm{B}$ activation in hyperoxia is associated with increased inflammation.

p50-/- neonatal lungs have increased apoptosis in byperoxia. In contrast to WT animals, neonatal $\mathrm{p} 50^{-/-}$mice had unchanged lung Bcl-2 protein levels after 72 hours of hyperoxia (Figure 10A). Additionally, lung DNA fragmentation was increased in hyperoxia-exposed $\mathrm{p} 50^{-/-}$neonatal compared with WT mice (Figure 9B). Furthermore, the neonatal $\mathrm{p} 50^{-/-}$mice demonstrated increased TUNEL-positive cells after 144 hours of hyperoxia compared with similarly exposed WT mice (Figure 10B). These data suggest that hyperoxia-mediated NF- $\mathrm{\kappa B}$ activation is associated with protection against apoptosis.

Neonatal $550^{-1-}$ mice have increased mortality in hyperoxia. Neonatal p50-/- mice had a significantly increased mortality compared with WT mice, whereas disruption of p50 in adults did not alter survival after hyperoxia (Figure 11); this further demonstrates that relative activation of NF- $\mathrm{KB}$ is important in mediating neonatal tolerance to hyperoxia.

\section{Discussion}

We show here that, in response to hyperoxic exposure, neonatal mouse lungs, unlike adult mouse lungs, activate NF-кB. Furthermore, disruption of NF- $\kappa \mathrm{B}$ in the neonatal mouse increased lung apoptosis and inflammation and lowered survival, suggesting an important role of NF-KB in neonatal tolerance to hyperoxia.

Several pathways can regulate $\mathrm{NF}-\kappa \mathrm{B}$ activation. The best understood of these involves the phosphorylation of the inhibitory protein $\mathrm{I}-\kappa \mathrm{B}$ at serines 32 and 36 for $\mathrm{I}-\kappa \mathrm{B} \alpha$ (serines 19 and 23 for $\mathrm{I}-\kappa \mathrm{B} \beta$, and serines 18 and 22 for $\mathrm{I}-\kappa \mathrm{B} \varepsilon$ ) by IKK. The core IKK complex consists of a heterodimer of IKK- $\alpha$ and IKK- $\beta$ (the catalytic subunits) that mediates the phosphorylation of $\mathrm{I}-\kappa \mathrm{B}$, and 2 IKK- $\gamma$ subunits (the regulatory subunits) that link the core to the upstream signaling molecules (see review, ref. 26). While IKK- $\beta$

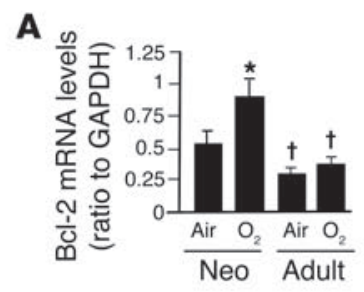

B

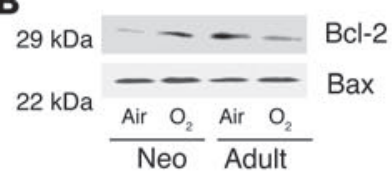

C
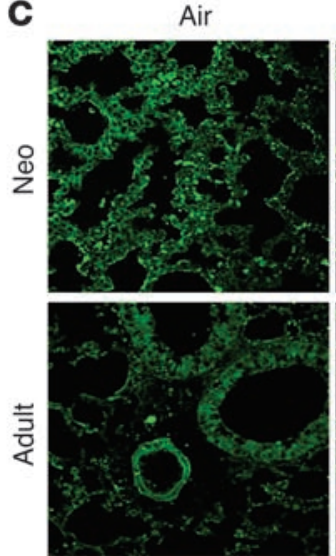

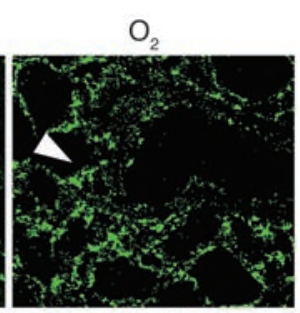

D
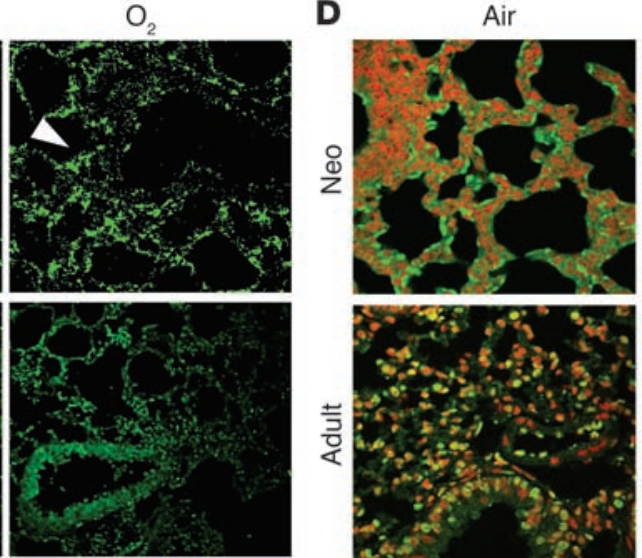

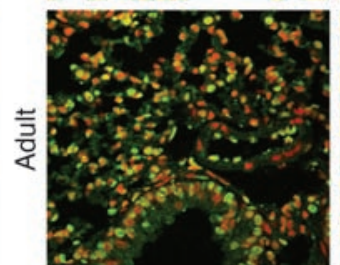

Figure 6

Bcl-2 expression and TUNEL staining in lungs of WT mice exposed to 72 hours of hyperoxia. (A) Bcl-2 mRNA levels were evaluated by RT-PCR. Densitometric values are expressed as a ratio to GAPDH. Values are the mean \pm SE of 3 separate experiments. ${ }^{*} P<0.05$ vs. airexposed mice. ${ }^{\dagger} P<0.05$ vs similarly exposed neonates. (B) Immunoreactive Bcl-2 and Bax protein levels. (C) Immunohistochemical staining of $\mathrm{Bcl}-2$ protein. Note that increased Bcl-2 was localized predominantly in the alveolar epithelial cells (arrowhead). (D) TUNEL staining in mouse lung tissues after hyperoxia. Note the relatively low number of TUNEL-positive cells in the neonatal lung but the high signal intensity in the similarly exposed adult lung (yellow). 


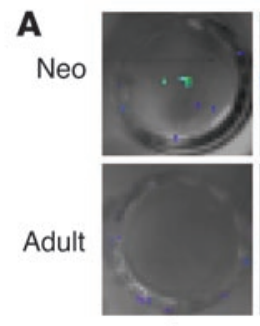

0

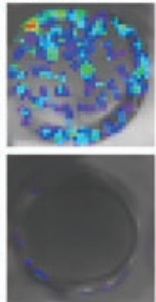

2

B

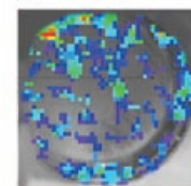
Control

C

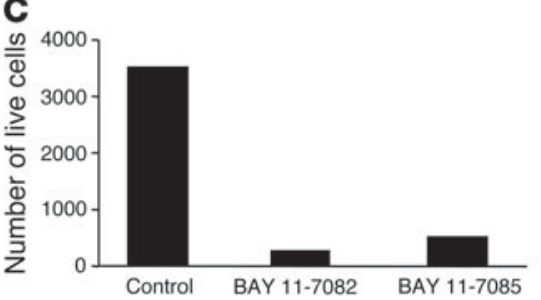

is essential for IKK activation in response to proinflammatory stimuli (27), IKK- $\alpha$ is important for IKK activation by a set of signals that do not affect the IKK- $\beta$ subunit (28). IKK- $\alpha$ can also act downstream of NF- $\kappa \mathrm{B}$-inducing kinase in a pathway that controls $\mathrm{p} 52 / \mathrm{p} 100$ processing independent of I- $\mathrm{\kappa B}$ phosphorylation (29). The activation of IKK- $\alpha$ and IKK- $\beta$ depends on their dimerization $(30,31)$ and association with the IKK- $\gamma$ regulatory subunit $(32$, 33). To this effect, cell lines that expressed a lower level of IKK- $\gamma$ had demonstrated a decrease in I- $\kappa \mathrm{B} \alpha$ phosphorylation and deg-

\section{Figure 7}

Effect of inhibition of $\mathrm{I}-\kappa \mathrm{B} \alpha$ phosphorylation on primary lung cells exposed to hyperoxia. (A) Visualization of NF-kB activation in primary lung cells cultured from NF-kB/luc Tg mice. (B) Effect of inhibition

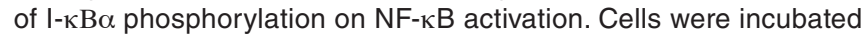
with $1 \mathrm{mM}$ BAY 11-7085 or BAY 11-7082 and then exposed to 24 hours of hyperoxia. Controls were incubated with $0.1 \%$ ethanol, the vehicle for BAY. Note the decreased light intensity after BAY treatment. (C) Cell viability was evaluated using trypan blue exclusion. The number of surviving cells in each group was assessed after 24 hours of hyperoxic exposure.

radation and NF- $\kappa \mathrm{B}$ activation (34). Our data showed that despite increased IKK- $\beta$, lung IKK- $\gamma$ was decreased in adults exposed to hyperoxia. The decreased IKK- $\gamma$ may explain, in part, the lesser $\mathrm{I}-\mathrm{KB}$ phosphorylation. In addition to IKK activation, successful NF- $\mathrm{KB}$ activation requires the recognition of phosphorylated $\mathrm{I}-\kappa \mathrm{B}$ by $\beta-\operatorname{TrCP}(35,36)$. The binding of I- $\mathrm{B}$ to the WD40 repeats located in the carboxyl-terminal domains of the $\beta$-TrCP leads to subsequent $26 \mathrm{~S}$ proteasome-dependent degradation (37). The increased $\beta$-TrCP protein levels observed in neonates were in agreement with rapid degradation of I- $\kappa \mathrm{B}$ and with the lower levels of

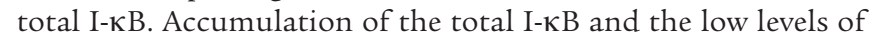
$\beta$-TrCP in the adult lung would predict lesser NF- $\mathrm{B}$ activation, as observed. Interestingly, p-JNK was selectively increased in the adult lung. This could be due to an activation of MeKK-1, a kinase that phosphorylates IKK, thereby resulting in synergistic phosphorylation of I-KB. However, increased p-JNK was not associ-

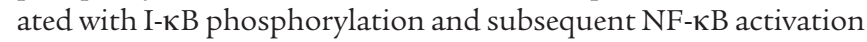
in adults. Other evidence demonstrates preferential AP-1 activation via the p-JNK pathway in hyperoxia-exposed adults (14).

Because NF- $\kappa \mathrm{B}$ can activate proinflammatory genes such as TNF- $\alpha$ and IL- $1 \beta$, it seems counterintuitive that an increase in $\mathrm{NF}-\kappa \mathrm{B}$ activation would be protective in hyperoxia. Nevertheless, the downstream effects of NF- $\mathrm{KB}$ activation are modulated by the

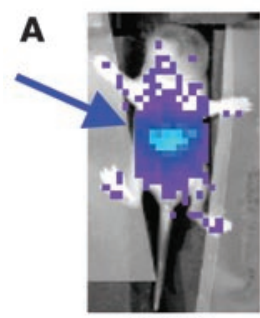

Pre- $\mathrm{O}_{2}$

\section{B}

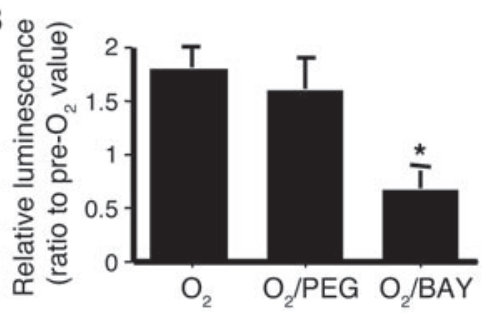

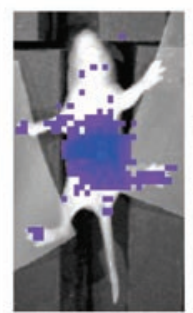

Pre- $\mathrm{O}_{2}$

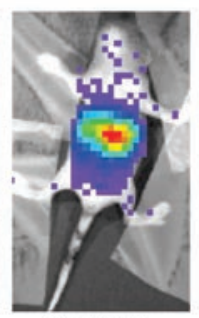

$\mathrm{O}_{2} / \mathrm{PEG}$

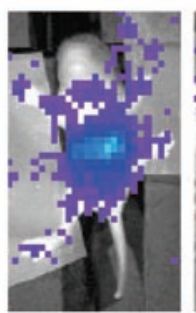

Pre- $\mathrm{O}_{2}$

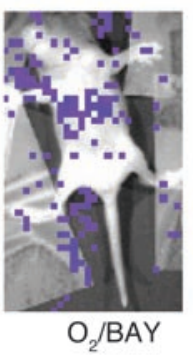

$\mathrm{pl}-\mathrm{\kappa B} \alpha$

$\mathrm{Bcl}-2$

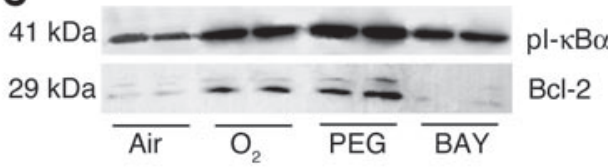

Figure 8

Inhibition of NF-KB activation in neonates injected with BAY. After 24 hours of hyperoxia, BAY-injected mice were injected with luciferin and anesthetized to allow for visualization (see Methods). (A) Photon emission was quantified over the lung area (arrow) and expressed as a ratio to pre- $\mathrm{O}_{2}$ for each animal. Pre- $\mathrm{O}_{2}$ lane: images taken prior to injection and hyperoxia; $\mathrm{O}_{2} / \mathrm{PEG}$ lane: mice injected with $\mathrm{PEG}$ (vehicle for $\mathrm{BAY}$ compounds); $\mathrm{O}_{2}$ /BAY lane: mice injected with BAY 11-7085. (B) Values represent the mean \pm SE of 3 experiments. ${ }^{*} P<0.05$ vs. polyethylglycol 400 (PEG) and uninjected. (C) $\mathrm{pl}-\mathrm{\kappa B} \alpha$ and $\mathrm{Bcl}-2$ protein levels in $\mathrm{C} 57 \mathrm{BL} / 6$ neonatal lung homogenates after 24 hours of hyperoxia and BAY injection. 
A
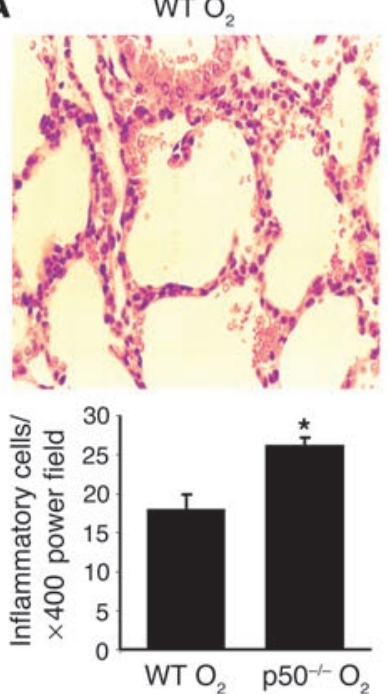

$\mathrm{p}^{-1-} \mathrm{O}_{2}$

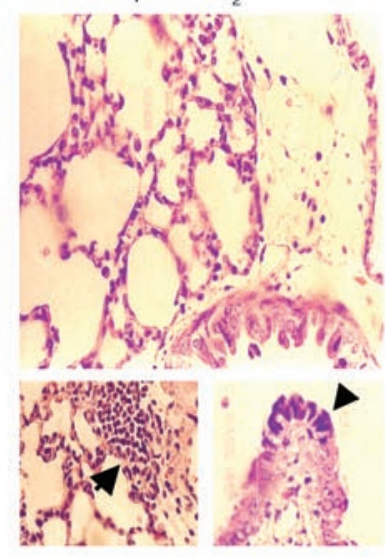

B

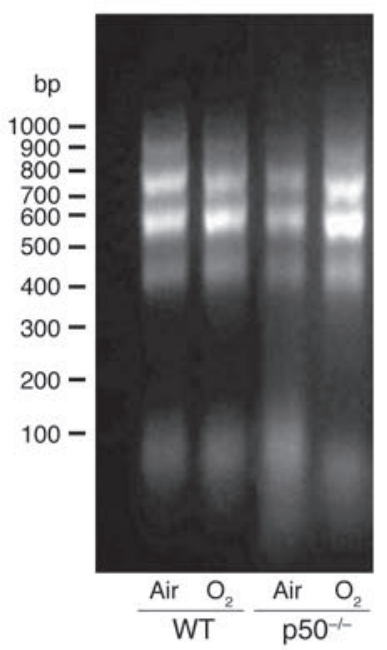

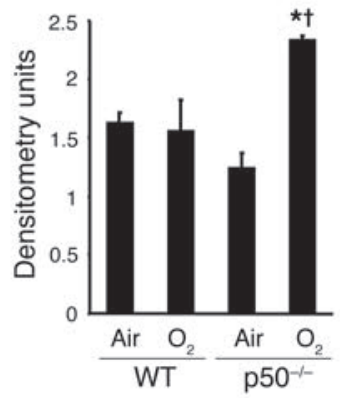

Figure 9

Lung injury in neonatal p50--- mice after hyperoxia. (A) Upper panels: Representative H\&E-stained lung tissue slide from neonatal WT and p50-/- mice exposed to hyperoxia for 144 hours $\left(\mathrm{O}_{2}\right)$. The slides were viewed at $\times 200$. Lower left panel: Inflammatory cells per power field. Values are the mean \pm SE of 3 animals in each group. ${ }^{*} P<0.05$ vs. oxygen-exposed WT mice. Lower right panels: Evaluation of lung injury after 144 hours of hyperoxia. Images were obtained at high magnification ( $\times 400)$; left, increased inflammatory cells in the bronchiolar ephithelium; right, bronchiolar epithelia necrosis. (B) Lung DNA fragmentation in WT and p50-/- mice exposed to 72 hours of hyperoxia. Genomic DNA was isolated, and DNA fragments were amplified by PCR. Left: Visualization of lung DNA fragments in ethidium bromide-stained $0.8 \%$ agarose gel. Right: Densitometric evaluation of the agarose gel .Values are the mean \pm SE of 3 experiments. ${ }^{*} P<0.05$ vs. air-exposed p50-/; ${ }^{\dagger} P<0.05$ vs. $\mathrm{O}_{2}$-exposed WT mice.

subunit composition of the complex. Specifically, p50 homodimers suppress LPS-mediated transcription of TNF- $\alpha$ despite evidence of binding at NF- $\mathrm{KB}$ consensus sequences $(38,39)$. This lack of transcription is due to the absence of a transcriptional activation domain on p50 homodimers, which compete with the transactivating p50/ p65 heterodimers. This results in decreased TNF- $\alpha$ gene expression. The inhibitory effect of p50 on TNF- $\alpha$ is further corroborated by enhanced TNF- $\alpha$ signal after hyperoxia in the p50-null mutant mice. Thus, the decrease in TNF- $\alpha$ could be partially explained by the predominance of $\mathrm{p} 50$ in the lung NF-KB complex as shown in our experiments. The balance of pro- and antiinflammatory effects likely dictates whether NF-кB activation is protective or detrimental. Lowered TNF- $\alpha$ likely contributes to an antiinflammatory milieu. The predominance of $\mathrm{p} 50 / \mathrm{p} 50$ in the whole-lung homogenates does not preclude abundance of $\mathrm{p} 50 / \mathrm{p} 65$ in subpopulations of lung cells such as alveolar macrophages (AMs) (40). Nevertheless, the neonatal lung has decreased influx and lowered retention of AMs compared with the adult lung after hyperoxia (41). This could explain the lack of significant $\mathrm{p} 65$ protein levels in the whole-lung homogenate. In another model, increased NF-кB activation was associated with increased $\mathrm{p} 65$ protein levels in neonatal rat brain after hypoxic exposure (42), suggesting tissue and/or stimulus specificity of NF- $\kappa \mathrm{B}$ activation.

\section{Figure 10}

Lung Bcl-2 and TUNEL staining in neonatal p50--- mice after hyperoxia. (A) Immunohistochemical staining of Bcl-2 protein in neonatal $\mathrm{p} 50^{-1-}$ mice exposed to 72 hours of air or hyperoxia. Note the unchanged Bcl2 protein levels after hyperoxia. (B) TUNEL staining in neonatal WT and $\mathrm{p} 50^{-/-}$mice after 144 hours of hyperoxia. Note the visibly increased amount of TUNEL-positive staining in the lungs of neonatal p50-/- mice as compared with the similarly exposed WT neonatal mice.
In addition to the antiinflammatory effect of p50 homodimers, cytoprotective gene products such as manganese superoxide dismutase (MnSOD) and glutathione peroxidase are regulated

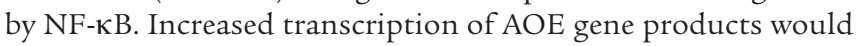
result in cytoprotection under hyperoxia (1). In support of this hypothesis, upregulation of lung AOEs is observed at birth with the transition to a relatively high-oxygen environment $(43,44)$. However, in other studies, increased protection against hyperoxia was due not to changes in AOE activity, but rather to alterations in DNA fragmentation $(24,45)$. Although MnSOD is upregulated in the neonatal lung after hyperoxia, the levels are still 3 times lower than that of adults $(46,47)$. Furthermore, the regulation of
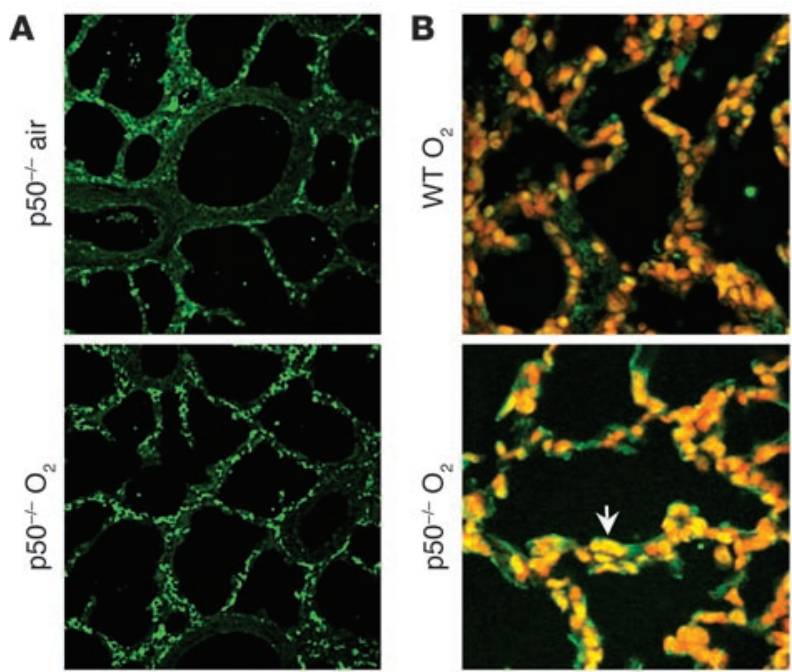

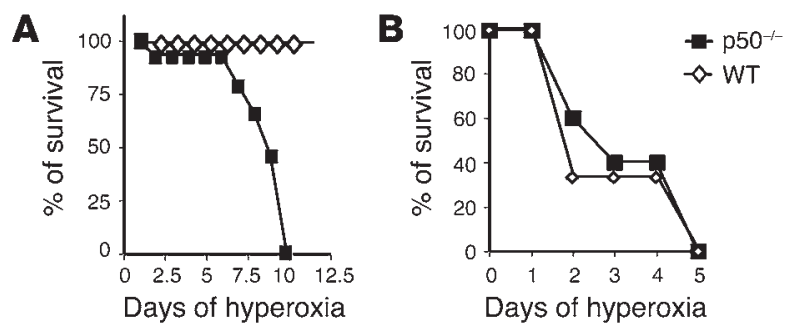

Figure 11

Survival of neonatal WT (A) and p50-/- (B) mice after chronic hyperoxia. Values are expressed as the percentage of surviving animals.

AOEs in the perinatal period is posttranscriptional $(48,49)$, making NF- $\mathrm{\kappa B}$-mediated transcriptional activation less likely.

Many antiapoptotic genes are regulated by NF- $\mathrm{kB}$, such as Bcl-x and Bcl-2 (50-53) as well as TRAF-1 and -2 and CIAP-1 (54). Disruption of NF-KB in the neonates resulted in increased DNA fragmentation and decreased lung Bcl-2 protein, suggesting increased apoptosis when NF- $\mathrm{kB}$ is not activated. The NF- $\mathrm{kB}-$ mediated Bcl-2 gene activation appears to contradict the repressor effect of the p50 homodimer on TNF- $\alpha$; however, studies also demonstrate that p50 homodimers can enhance Bcl-2 gene transcription by binding to the $\mathrm{Bcl}-2$ promoter (55). Most importantly, the NF- $\mathrm{KB}$-mediated changes in apoptosis were associated with decreased hyperoxic survival in the neonates, further demonstrating the importance of NF-KB activation in tolerance to hyperoxia. It is clear that apoptosis or DNA fragmentation affects cell survival by activating death signals, but it is less evident why lung apoptosis or DNA fragmentation significantly affects survival during acute exposure to hyperoxia. Perhaps apoptosis and subsequent $\mathrm{Na}^{+} / \mathrm{K}^{+}$ATPase dysfunction and ATP depletion lead to increased lung edema and mortality, as suggested by others (56).

In summary, we demonstrate enhanced lung NF- $\kappa \mathrm{B}$ activation in neonates exposed to hyperoxia as compared with adults. This is due to increased lung IKK protein levels, increased lung $\mathrm{I}-\kappa \mathrm{B} \alpha$ phosphorylation, increased lung $\beta$-TrCP protein levels, and increased lung total I- $\mathrm{\kappa B} \alpha$ degradation as demonstrated in the classical NF- $\mathrm{KB}$ activation pathway. We speculate that preferential NF- $\mathrm{BB}$ activation in the neonatal lungs provides protection against hyperoxia by increasing antiinflammatory and antiapoptotic gene expression.

\section{Methods}

\section{Animal model}

Lactating dams with their litters of neonatal mice ( $<12$ hours old) as well as adult C57BL/6 (WT) mice ( 2 months old; adult) were purchased from Charles River Laboratories Inc.

NF-кB/luc Tg mice were a gift from Mercedes Rincon (University of Vermont, Burlington, Vermont, USA). These mice are on a B10.Br background (M. Rincon, personal communication). The transgene consists of the luciferase gene driven by 2 copies of the NF-КB DNA-binding consensus sequence from the Igk enhancer, in the context of the $\mathrm{c}$-fos minimal promoter (57). These mice have previously been used as an index of NF- $\mathrm{KB}$ activation in other studies $(41,57)$.

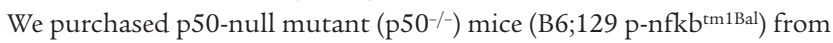
The Jackson Laboratory. These mice have been backcrossed to a C57BL/6 background over 5 generations. WT controls were C57BL/6 mice. Disrup- tion of NF- $\mathrm{KB}$ binding was verified in the neonatal lung using electrophoretic mobility shift assay (EMSA) (data not shown).

Animal protocols were reviewed and approved by the Animal Care Institutional Review Panels of Stanford University and the Children's Hospital of Philadelphia.

\section{Primary lung cultures}

Primary lung cultures were established from neonatal and adult NF-КB/ luc $\mathrm{Tg}$ mice. The lung tissue was finely minced and placed in a $60-\mathrm{mm}$ culture dish with DMEM with 10\% FCS. Explanted cultures were grown to $80 \%$ confluence then replated in 6-well plates and allowed to reach $70 \%$ confluence prior to experiments.

\section{Inbibition of $p I-\kappa B \alpha$}

Prior to hyperoxia, 4-day-old NF-kB/luc or C57BL/6 mice were injected intraperitoneally with $20 \mathrm{mg} / \mathrm{kg}$ BAY 11-7085 (BIOMOL International L.P.), an inhibitor of I- $\mathrm{KB}$ phosphorylation. This dose has been previously shown to inhibit NF- $\kappa \mathrm{B}$ activation in rats (58). Control animals were injected with vehicle (polyethylglycol 400 diluted $1: 5$ in $5 \% \mathrm{BSA} / \mathrm{H}_{2} \mathrm{O}$ ). To evaluate the effect of $\mathrm{pI}-\mathrm{\kappa B}$ inhibition on cell viability, primary lung cells were incubated with $1 \mathrm{mM}$ BAY 11-7085 or BAY 11-7082 (BIOMOL Research Laboratories Inc.), another inhibitor of I- $\kappa \mathrm{B}$ phosphorylation, prior to hyperoxic exposure. Cells incubated with $0.1 \%$ ethanol (the vehicle for BAY) served as controls.

\section{Hyperoxic exposure}

In vivo. Neonatal or adult mice were exposed to hyperoxia $\left(\mathrm{O}_{2}>95 \%\right)$ or air for 0-72 hours as described previously (14). A subgroup of animals was also exposed chronically to hyperoxia (>7 days). The number of surviving animals was determined daily until all animals had died.

In vitro. Primary lung cells from the NF- $\mathrm{KB} / \mathrm{luc} \mathrm{Tg}$ mice were incubated in an oxygen-filled humidified chamber $\left(95 \% \mathrm{O}_{2} / 5 \% \mathrm{CO}_{2}, 1\right.$ standard atmosphere) (Praxair Inc.) for 24 hours. A blood-gas analyzer was used to ensure equilibration of the oxygen with medium.

\section{In vivo imaging of bioluminescent signal}

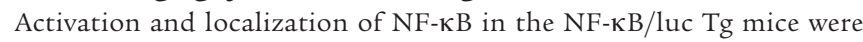
visualized using an In Vivo Imaging System (IVIS; Xenogen Corp.) as previously described (59). Twenty minutes prior to imaging, a mixture of the substrate luciferin $(150 \mathrm{mg} / \mathrm{kg}$ body weight $)$ and the anesthetic agents ketamine and xylazine ( $5 \mathrm{ml} / \mathrm{kg}$ body weight) was injected intraperitoneally into the adult $\mathrm{Tg}$ mice to obviate movement. The neonatal mice were injected in the same manner but without the anesthetics; rather the pups were immobilized with adhesive tape. The light emitted from the luciferase-expressing cells of the Tg mice was detected with the IVIS. To allow for quantification and normalization, the light intensity and photon counts were determined from identical areas of the lungs of live animals using Living Image software (Xenogen Corp.).

For visualization of NF- $\mathrm{KB}$ activation in vitro, air- or hyperoxia-exposed primary lung cells were incubated with $150 \mu \mathrm{g} / \mathrm{ml}$ luciferin for 15 minutes at room temperature. After detection of emitted photons with the IVIS, a pseudo-color image representing light intensity was generated and photon emission was quantitated with Living Image software (Xenogen Corp.).

\section{Preparation of nuclear proteins}

Freshly collected whole lungs without evidence of hemorrhage were perfused with $10 \% \mathrm{KCl}$ injected first through the heart and then through the trachea to remove all red blood cells. The lungs were then washed with cold $0.1 \mathrm{M}$ phosphate buffer ( $\mathrm{pH}$ 7.4) and directly homogenized in collection buffer provided by a nuclear protein extraction kit (Pierce Biotech- 
nology Inc.). Nuclear and cytosolic fractions were extracted according to the manufacturer's instructions. Aliquots were then stored at $-70^{\circ} \mathrm{C}$. Prior to assays, nuclear and cytosolic protein contents were determined by the method of Bradford (Bio-Rad Laboratories Inc.).

\section{Evaluation of lung $N F-\kappa B$ binding in hyperoxia by EMSA assay}

A ${ }^{32} \mathrm{P}$-labeled oligonucleotide with the consensus sequence for NF- $\mathrm{KB}\left(5^{\prime}\right.$ AGTTGAGGGGACTTTCCCAGGC-3') (Santa Cruz Biotechnology Inc.) was used as a probe to evaluate NF- $\mathrm{KB}$ binding ability as described previously (14). To identify nonspecific binding of the nuclear proteins, competition reactions were performed by addition of either 100-fold excess of non-radiolabeled NF- $\mathrm{KB}$ or 100-fold excess of non-radiolabeled mutated NF-KB (5'-AGTTGAGGCGACTTTCCCAGGC-3') to the reaction mixtures prior to electrophoresis.

In separate experiments, in order to identify the NF- $\mathrm{BB}$ subunit proteins in the complex, $2 \mu \mathrm{l}$ of p50, p52, p65, RelB, or cRel antibodies (catalog no. sc-1190, sc-298, sc-372, sc-226, or sc-71, respectively; Santa Cruz Biotechnology Inc.) was incubated with the nuclear proteins prior to addition of the radiolabeled probe to visualize any supershift-retarded bands in the NF- $\mathrm{\kappa B}$ complex.

\section{Evaluation of lung $I-\kappa B \alpha, p I-\kappa B \alpha$, and $\beta-\operatorname{Tr} C P$ proteins}

For the detection of I- $\kappa \mathrm{B} \alpha$ and $\mathrm{pI}-\kappa \mathrm{B} \alpha$, lung cytosolic proteins were electrophoresed on a $12 \%$ polyacrylamide gel according to the methods of Laemmli (60). Lung nuclear fractions were used for determination of $\beta$-TrCP protein levels. Proteins were transferred to a PVDF membrane (Bio-Rad Laboratories Inc.). Blots were then briefly washed in $1 \times \mathrm{PBS}$ and then incu-

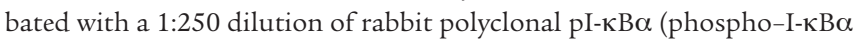
ser32) antibodies (Cell Signaling Technology Inc.) and of rabbit polyclonal $\beta$-TrCP (Santa Cruz Biotechnology Inc.) for 2 hours at room temperature in a blocking solution ( $5 \%$ nonfat milk in PBS containing $0.05 \%$ Tween- 20 [T-PBS]). Blots were washed in T-PBS and incubated with a 1:4,000 dilution of HRP-conjugated goat anti-mouse IgG (Santa Cruz Biotechnology Inc.). The antigen-antibody signal was then visualized as previously described

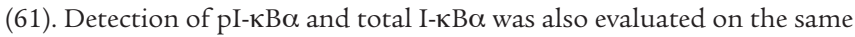
blot using polyclonal I- $\kappa \mathrm{B} \alpha$ antibody (Santa Cruz Biotechnology Inc.). Cell lysates incubated with TNF- $\alpha$ (Cell Signaling Technology Inc.) were used as positive controls. Equal loading was verified by Coomassie blue staining. Densitometric evaluation was used for quantification.

\section{Evaluation of lung IKK core subunit protein, JNK, and p-JNK}

To determine whether kinases upstream of I- $\kappa \mathrm{B} \alpha$ were developmentally regulated, groups of $\mathrm{C} 57 \mathrm{BL} / 6$ mice aged $0,3,7,14,21$, and 60 days were exposed to hyperoxia for 72 hours. Whole-lung homogenates were evaluated for IKK- $\alpha$, IKK- $\beta$, IKK- $\gamma$ (Cell Signaling Technology Inc.), JNK, and p-JNK (Santa Cruz Biotechnology Inc.) immunoreactive proteins using Western analysis.

\section{Localization of $N F-\kappa B$ activation in the lung of $N F-\kappa B / l u c T g$ mice}

Immunohistochemical staining of luciferase protein, as an index of NF- $\kappa B$ activation, was performed on $6-\mu \mathrm{m}$ paraffin-embedded lung tissue sections as previously described (62). The lung tissue slides were first incubated with a 1:50 dilution of goat anti-firefly luciferase antibody (Novus Biologicals Inc.) overnight. Subsequently, the slides were incubated with a 1:250 dilution of a Cy5-conjugated anti-goat IgG (Novus Biologicals Inc.) antibody for 1 hour at room temperature. After several washes, the slides were further incubated with a 1:25 dilution of FITC-labeled rat anti-mouse CD68 antibody (Serotec Inc.) to allow for colocalization to macrophages. Slides were viewed with a Nikon confocal microscope (Nikon Inc.) using a laser scanning unit (model 2010; Molecular Dynamics) as previously described (61).

\section{Evaluation of cell viability}

Trypan blue exclusion was used to determine cell viability. Cells were first released with $0.05 \%$ trypsin-EDTA. Twenty-microliter aliquots were then mixed with $20 \mu \mathrm{l}$ of $0.5 \%$ trypan blue, and viable cells were counted using a hematocytometer. The numbers of dead (stained) cells were then expressed as a ratio of the total (stained and unstained) cells counted.

\section{Evaluation of apoptosis}

DNA laddering assay. Genomic DNA was extracted from the lung tissues using a commercially available kit (Bdtract Genomic DNA Isolation Kit, catalog no. SA-40001; Maxim Biotech Inc.). Fragmented DNA was conjugated with extension primers and amplified by PCR (PCR kits for DNA ladder assay, catalog no. APO-DNA-1; Maxim Biotech Inc.). Equal volume of each PCR product and an aliquot of a 100-bp standard DNA ladder (New England Biolabs Inc.) were loaded onto $2 \%$ agarose gels with ethidium bromide. The gels were visualized using a UV imager.

TUNEL assay. Paraffin-embedded slides were analyzed for DNA strand breaks by fluorescent enzymatic labeling of the free $3^{\prime} \mathrm{OH}$ termini of modified nucleotides using a commercially available kit (In Situ Cell Death Detection Kit, Fluorescein; Roche Diagnostics Corp.). Tissue sections were counterstained with $0.1 \mu \mathrm{M}$ TO-PRO-3 iodide (Invitrogen Corp.). The slides were visualized with a laser scanning confocal microscope set at excitation/emission wavelengths of 488/510 nm (for TUNEL staining) and $642 / 661 \mathrm{~nm}$ (for TO-PRO-3 staining).

\section{Determination of antiapoptotic protein $\mathrm{Bcl}-2$ and proapoptotic protein Bax}

Lung homogenates were evaluated for changes in $\mathrm{Bcl}-2$ and Bax protein levels by Western analysis using rabbit anti-mouse polyclonal antibodies against Bcl-2 (Cell Signaling Technology Inc.) and Bax (Santa Cruz Biotechnology Inc.) at a 1:1,000 dilution in 5\% milk.

\section{Evaluation of cytokine and Bcl-2 mRNA levels}

Total RNA was isolated from freshly prepared lung tissues using TRIZOL reagent (Invitrogen Corp.). First-strand cDNA was synthesized from the RNA by reverse transcription using AMV reverse transcriptase (Invitrogen Corp.). Panels of pro- and antiinflammatory genes (TNF- $\alpha$, IL-1 $\beta$, IL- 6 , GM-CSF, and TGF- $\beta$ ), Bcl-2 gene, and the housekeeping gene GAPDH were amplified with PCR using $100 \mu \mathrm{g}$ of cDNA as a template (BioSource International Inc.). PCR signals for each gene were normalized to the signal for GAPDH.

\section{Localization of Bcl-2 protein levels in the lung}

To localize Bcl-2 expression within the lung, tissue sections were incubated with a 1:20 dilution of polyclonal anti-Bcl-2 antibody (Santa Cruz Biotechnology Inc.) overnight and a 1:500 dilution of FITC-conjugated anti-rabbit IgG (Caltag Laboratories Inc.) for 1 hour. Slides were viewed as described previously (28).

\section{Evaluation of lung injury}

After dissection, lungs were immediately inflated with $10 \%$ neutral buffered formalin and then immersed in the formalin. The tissues were subjected to standard histological processing and paraffin embedding. Six-micronthick sections were deparaffinized, hydrated, and stained with a routine H\&E stain, for evidence of inflammation, necrosis, or perivascular edema. Inflammatory cells were counted in 16 high-power fields per slide. The average number of inflammatory cells per high-power field was calculated.

\section{Statistical analysis}

For comparison between treatment groups, the null hypothesis that there is no difference between treatment means was tested by a single-factor 
ANOVA for multiple groups or unpaired $t$ test for 2 groups (StatView 4.02; SAS Institute Inc.). Statistical significance $(P<0.05)$ between and within groups was determined by means of the Fisher method of multiple comparisons. Statistical differences in survival were evaluated by Kaplan-Meier analysis.

\section{Acknowledgments}

We thank Mercedes Rincon for providing the NF-кB mice and for advice, for which we are also grateful to Brooke Mossman (University of Vermont). We also thank Ronald J. Wong (Stanford University) for his critical and careful review of the manuscript. This work was funded by NIH grant HL58752 (to P.A. Dennery), a career investigator award from the American Lung
Association (to P.A. Dennery), and gifts from the Mary L. Johnson Research Fund, the Court Ballirger Fund, and the Christopher Hess Fund of Stanford University through endowment to the Division of Neonatology.

Received for publication June 24, 2003, and accepted in revised form July 20, 2004.

Address correspondence to: Phyllis A. Dennery, Department of Pediatrics, University of Pennsylvania School of Medicine, Children's Hospital of Philadelphia, 34th and Civic Center Boulevard, Philadelphia, Pennsylvania 19104, USA. Phone: (215) 590-1653; Fax: (267) 426-5632; E-mail: dennery@email.chop.edu.
1. Frank, L., Bucher, J.R., and Roberts, R.J. 1978. Oxygen toxicity in neonatal and adult animals of various species. J. Appl. Physiol. 45:699-704.

2. Hass, M.A., and Massaro, D. 1987. Differences in $\mathrm{CuZn}$ superoxide dismutase induction in lungs of neonatal and adult rats. Am. J. Physiol. 253:C66-C70.

3. Hoffman, M., Stevens, J.B., and Autor, A.P. 1980. Adaptation to hyperoxia in the neonatal rat: kinetic parameters of the oxygen-mediated induction of lung superoxide dismutases, catalase and glutathione peroxidase. Toxicology. 16:215-225.

4. Ischiropoulos, H., Nadziejko, C.E., Kumae, T., and Kikkawa, Y. 1989. Oxygen tolerance in neonatal rats: role of subcellular superoxide generation. $A m$. J. Physiol. 257:L411-L420.

5. Crapo, J.D., McCord, J.M., and Fridovich, I. 1978. Preparation and assay of superoxide dismutases. Methods Enzymol. 53:382-393.

6. Crapo, J.D., and Tierney, D.F. 1974. Superoxide dismutase and pulmonary oxygen toxicity. Am.J. Physiol. 226:1401-1407.

7. Davis, W.B., Rennard, S.I., Bitterman, P.B., and Crystal, R.G. 1983. Pulmonary oxygen toxicity. Early reversible changes in human alveolar structures induced by hyperoxia. N. Engl. J. Med. 309:878-883.

8. Frank, L., Summerville, J., and Massaro, D. 1980. Protection from oxygen toxicity with endotoxin. Role of the endogenous antioxidant enzymes of the lung. J. Clin. Invest. 65:1104-1110.

9. Deneke, S.M., and Fanburg, B.L. 1980. Normobaric oxygen toxicity of the lung. N. Engl. J. Med. 303:76-86.

10. Ward, N.S., et al. 2000. Interleukin-6-induced protection in hyperoxic acute lung injury. Am. J. Respir Cell Mol. Biol. 22:535-542.

11. Joyce-Brady, M., Oakes, S.M., Wuthrich, D., and Laperche, Y. 1996. Three alternative promoters of the rat gamma-glutamyl transferase gene are active in developing lung and are differentially regulated by oxygen after birth. J. Clin. Invest. 97:1774-1779.

12. Franco, M.L., et al. 2002. LPS-induced lung injury in neonatal rats: changes in gelatinase activities and consequences on lung growth. Am. J. Physiol. Lung Cell. Mol. Physiol. 282:L491-L500.

13. Buckley, S., and Warburton, D. 2002. Dynamics of metalloproteinase-2 and -9, TGF-beta, and uPA activities during normoxic vs. hyperoxic alveolarization. Am. J. Physiol. Lung Cell. Mol. Physiol. 283:L747-L754.

14. Yang, G., Madan, A., and Dennery, P.A. 2000. Maturational differences in hyperoxic AP-1 activation in rat lung. Am. J. Physiol. Lung Cell. Mol. Physiol. 278:L393-L398.

15. Beraud, C., Henzel, W.J., and Baeuerle, P.A. 1999. Involvement of regulatory and catalytic subunits of phosphoinositide 3-kinase in NF-kappaB activation. Proc. Natl. Acad. Sci. U. S. A. 96:429-434.

16. Lee, F.S., Peters, R.T., Dang, L.C., and Maniatis, T. 1998. MEKK1 activates both IkappaB kinase alpha and IkappaB kinase beta. Proc. Natl. Acad. Sci. U. S. A. 95:9319-9324.

17. Janssen-Heininger, Y.M., Macara, I., and Mossman, B.T. 1999. Cooperativity between oxidants and tumor necrosis factor in the activation of nuclear factor (NF)-kappaB: requirement of Ras/mitogenactivated protein kinases in the activation of NF-kappaB by oxidants. Am. J. Respir. Cell Mol Biol. 20:942-952.

18. Beg, A.A., and Baltimore, D. 1996. An essential role for NF-kappaB in preventing TNF-alpha-induced cell death. Science. 274:782-784.

19. Liu, Z.G., Hsu, H., Goeddel, D.V., and Karin, M. 1996. Dissection of TNF receptor 1 effector functions: JNK activation is not linked to apoptosis while NF-kappaB activation prevents cell death. Cell. 87:565-576.

20. Van Antwerp, D.J., Martin, S.J., Kafri, T., Green, D.R., and Verma, I.M. 1996. Suppression of TNFalpha-induced apoptosis by NF-kappaB. Science. 274:787-789.

21. Wang, C.Y., Mayo, M.W., and Baldwin, A.S., Jr. 1996. TNF- and cancer therapy-induced apoptosis: potentiation by inhibition of NF-kappaB. Science. 274:784-787.

22. Kaltschmidt, B., et al. 2000. The pro- or antiapoptotic function of NF-kappaB is determined by the nature of the apoptotic stimulus. Eur. J. Biochem. 267:3828-3835.

23. Li, Y., et al. 1997. Nuclear factor-kappaB is activated by hyperoxia but does not protect from cell death. J. Biol. Chem. 272:20646-20649.

24. Franek, W.R., et al. 2001. Hyperoxia inhibits oxidant-induced apoptosis in lung epithelial cells. J. Biol. Chem. 276:569-575.

25. Haddad, J.J., and Land, S.C. 2000. O(2)-evoked regulation of HIF-1alpha and NF-kappaB in perinatal lung epithelium requires glutathione biosynthesis. Am. J. Physiol. Lung Cell. Mol. Physiol. 278:L492-L503.

26. Zandi, E., and Karin, M. 1999. Bridging the gap: composition, regulation, and physiological function of the IkappaB kinase complex. Mol. Cell. Biol. 19:4547-4551.

27. Li, Q., Van Antwerp, D., Mercurio, F., Lee, K.F., and Verma, I.M. 1999. Severe liver degeneration in mice lacking the IkappaB kinase 2 gene. Science. 284:321-325.

28. Cao, Y., et al. 2001. IKKalpha provides an essential link between RANK signaling and cyclin D1 expression during mammary gland development. Cell. 107:763-775.

29. Senftleben, U., et al. 2001. Activation by IKKalpha of a second, evolutionary conserved, NF-kappa B signaling pathway. Science. 293:1495-1499.

30. Mercurio, F., et al. 1997. IKK-1 and IKK-2: cytokineactivated IkappaB kinases essential for NF-kappaB activation. Science. 278:860-866.

31. Zandi, E., Chen, Y., and Karin, M. 1998. Direct phosphorylation of IkappaB by IKKalpha and
IKKbeta: discrimination between free and NF-kappaB-bound substrate. Science. 281:1360-1363.

32. Makris, C., et al. 2000. Female mice heterozygous for IKK gamma/NEMO deficiencies develop a dermatopathy similar to the human X-linked disorder incontinentia pigmenti. Mol. Cell. 5:969-979.

33. May, M.J., et al. 2000. Selective inhibition of NF-kappaB activation by a peptide that blocks the interaction of NEMO with the IkappaB kinase complex. Science. 289:1550-1554.

34. Rothwarf, D.M., Zandi, E., Natoli, G., and Karin, M. 1998. IKK-gamma is an essential regulatory subunit of the IkappaB kinase complex. Nature. 395:297-300.

35. Karin, M., and Ben-Neriah, Y. 2000. Phosphorylation meets ubiquitination: the control of NF- $\mathrm{KB}$ activity. Annu. Rev. Immunol. 18:621-663.

36. Spencer, E., Jiang, J., and Chen, Z.J. 1999. Signalinduced ubiquitination of IkappaBalpha by the F-box protein Slimb/beta-TrCP. Genes Dev. 13:284-294.

37. Yaron, A., et al. 1998. Identification of the receptor component of the IkappaBalpha-ubiquitin ligase. Nature. 396:590-594.

38. Udalova, I.A., et al. 2000. Functional consequences of a polymorphism affecting NF-kappaB p50-p50 binding to the TNF promoter region. Mol. Cell. Biol. 20:9113-9119.

39. Bohuslav, J., et al. 1998. Regulation of an essential innate immune response by the 550 subunit of NF$\kappa \mathrm{B}$. J. Clin. Invest. 102:1645-1652.

40. Leeper-Woodford, S.K., and Detmer, K. 1999. Acute hypoxia increases alveolar macrophage tumor necrosis factor activity and alters NF-kappaB expression. Am. J. Physiol. 276:L909-L916.

41. Millet, I., et al. 2000. Inhibition of NF-kappaB activity and enhancement of apoptosis by the neuropeptide calcitonin gene-related peptide. J. Biol. Chem. 275:15114-15121.

42. Simakajornboon, N., Gozal, E., and Gozal, D. 2001. Developmental patterns of NF-kappaB activation during acute hypoxia in the caudal brainstem of the rat. Brain Res. Dev. Brain Res. 127:175-183.

43. Clerch, L.B., Wright, A.E., and Coalson, J.J. 1996. Lung manganese superoxide dismutase protein expression increases in the baboon model of bronchopulmonary dysplasia and is regulated at a posttranscriptional level. Pediatr. Res. 39:253-258.

44. Clerch, L.B., Iqbal, J., and Massaro, D. 1991. Perinatal rat lung catalase gene expression: influence of corticosteroid and hyperoxia. Am. J. Physiol. 260:L428-L433.

45. Waxman, A.B., et al. 1998. Targeted lung expression of interleukin-11 enhances murine tolerance of $100 \%$ oxygen and diminishes hyperoxia-induced DNA fragmentation. J. Clin. Invest. 101:1970-1982.

46. Autor, A.P., Frank, L., and Roberts, R.J. 1976. Developmental characteristics of pulmonary superoxide dismutase: relationship to idiopathic respiratory distress syndrome. Pediatr. Res. 10:154-158. 
47. Frank, L., and Groseclose, E.E. 1984. Preparation for birth into an O2-rich environment: the antioxidant enzymes in the developing rabbit lung. Pediatr. Res. 18:240-244.

48. Clerch, L.B., and Massaro, D. 1992. Rat lung antioxidant enzymes: differences in perinatal gene expression and regulation. Am. J. Physiol. 263:L466-L470.

49. Clerch, L.B., and Massaro, D. 1993. Tolerance of rats to hyperoxia. Lung antioxidant enzyme gene expression. J. Clin. Invest. 91:499-508.

50. Barazzone, C., and White, C.W. 2000. Mechanisms of cell injury and death in hyperoxia: role of cytokines and Bcl-2 family proteins. Am. J. Respir. Cell Mol. Biol. 22:517-519.

51. Lu, P.J., Lu, Q.L., Rughetti, A., and Taylor-Papadimitriou, J. 1995. bcl-2 overexpression inhibits cell death and promotes the morphogenesis, but not tumorigenesis of human mammary epithelial cells. J. Cell Biol. 129:1363-1378.

52. Pritchard, D.M., Potten, C.S., Korsmeyer, S.J., Roberts, S., and Hickman, J.A. 1999. Damage-induced apoptosis in intestinal epithelia from bcl-2-null and bax-null mice: investigations of the mechanistic determinants of epithelial apoptosis in vivo. Oncogene. 18:7287-7293.

53. Wang, C.Y., Cusack, J.C., Jr., Liu, R., and Baldwin, A.S., Jr. 1999. Control of inducible chemoresistance: enhanced anti-tumor therapy through increased apoptosis by inhibition of NF-kappaB. Nat. Med. 5:412-417.

54. Wang, C.Y., Mayo, M.W., Korneluk, R.G., Goeddel, D.V., and Baldwin, A.S., Jr. 1998. NF-kappaB antiapoptosis: induction of TRAF1 and TRAF2 and c-IAP1 and c-IAP2 to suppress caspase-8 activation. Science. 281:1680-1683.

55. Kurland, J.F., et al. 2001. NF-kappaB1 (p50) homodimers contribute to transcription of the bcl-2 oncogene. J. Biol. Chem. 276:45380-45386.

56. Youssef, J.A., et al. 1999. Influence of inhaled nitric oxide and hyperoxia on Na,K-ATPase expression and lung edema in newborn piglets. Biol. Neonate. 75:199-209.
57. Voll, R.E., et al. 2000. NF-kappa B activation by the pre-T cell receptor serves as a selective survival signal in $\mathrm{T}$ lymphocyte development. Immunity. 13:677-689.

58. Pierce, J.W., et al. 1997. Novel inhibitors of cytokine-induced IkappaBalpha phosphorylation and endothelial cell adhesion molecule expression show anti-inflammatory effects in vivo. J. Biol. Chem. 272:21096-21103.

59. Contag, C.H., et al. 1997. Visualizing gene expression in living mammals using a bioluminescent reporter. Photochem. Photobiol. 66:523-531.

60. Laemmli, U.K. 1970. Cleavage of structural proteins during the assembly of the head of bacteriophage T4. Nature. 227:680-685.

61. Dennery, P.A., et al. 1998. Oxygen toxicity and iron accumulation in the lungs of mice lacking heme oxygenase-2. J. Clin. Invest. 101:1001-1011.

62. Dennery, P.A., et al. 2003. Developmental expression of heme oxygenase in the rat lung. Pediatr. Res. 53:42-47. 